\title{
Online Buying Behaviour with Special Reference to Kadapa Town in Andhra Pradesh State
}

\section{K. Khasimpeera, M. Sugunatha Reddy}

\begin{abstract}
Web based shopping is a type of trade which enables customers to legitimately purchase merchandise or administrations from vender utilizing an internet browser. The business person Michael Aldrich imagined web based shopping in 1979. The investigation centers around online customers inclinations and issues on different internet shopping advertisers. Survey was utilized to gather the essential information. The study area is restricted only in kadapa town of Andhra Pradesh with sample size of 150 respondents.

Key Words: Web shopping, versatile trade.
\end{abstract}

\section{INTRODUCTION}

In previous days the clients are used to go to various shops before acquiring what they want. After improvement of web shopping the clients are easily acquiring what they need from shops. It is very convenient to the consumers' easy access to have the items from any market from any country.

\section{Online Buying:}

Web based shopping is a type of business enables buyers straightforward purchase merchandise or administrations using an internet. Versatile trade depicts buying portablestreamline webpage application. Business visionary contact web based framework associated an altered residential TV to a constant exchange handling PC through a local phone line. In 1980, Walk proceeded to dispatch Redifon'sOffice, which permitted purchasers, clients, specialists, merchants, providers and administration organizations associated frameworks exchanges finished items.

\section{REVIEW OF LITERATURE}

Satisfaction is important to the individual consumer because it reflects a positive outcome from the outlay of scarce resources and/or the fulfillment of unmet needs (Day \& Landon, 1977). Traditional consumer behavior online shopping has its own model, which the buying process starts from the problem recognition, information search, evaluation of alternatives, and purchase behavior (Crawford, 1997).The internet users were having positive attitude and online buying of products/services. There by exists a need for developing awareness about consumers' rights and cyber laws (Vyas and Shrinivas, 2002).

Revised Manuscript Received on January 29, 2020.

* Correspondence Author

Khasimpeera.K*, Assistant Professor, Balaji institute of I.T \& Management, Kadapa, Andhra Pradesh, India.

Dr. Sugunatha Reddy, Assistant, KSRM College of Engineering, Kadapa, Andhra Pradesh, India.

(c) The Authors. Published by Blue Eyes Intelligence Engineering and Sciences Publication (BEIESP). This is an open access article under the CC BY-NC-ND license (http://creativecommons.org/licenses/by-nc-nd/4.0/)
Website design, reliability, product variety and delivery performances are the four key factors influencing consumers' satisfaction of online shopping (Alam and Yasim 2010).

\section{OBJECTIVES OF THE STUDY}

The objectives of the study are:

$\checkmark \quad$ Promoting a service or product online

$\checkmark$ Selling a service or product

$\checkmark$ Providing product support or customer service

$\checkmark$ Providing corporate information

$\checkmark$ Establishing brand awareness and corporate identity.

\section{DESIGN OF THE STUDY}

This study Confine to exclusive customers of kadapa town of Andhra Pradesh,

\section{Data Collection:}

This study investigates 200 samples and makes information data collection. Primary data collecting by using survey method. Secondary data built the scope and structure by asking questionnaire among the buyers.

The following Table 01.Personal Profile of the Respondents in respect of Monthly income:-

Table 01: Profile of the Respondents

\begin{tabular}{|l|c|c|c|}
\hline Monthly Income & Interval & Percent & $\begin{array}{c}\text { Cumulative } \\
\text { Per cent }\end{array}$ \\
\hline $\begin{array}{l}\text { Rs. Up to } \\
\text { Rs.10,000 }\end{array}$ & 23 & 11.5 & 11.5 \\
\hline $\begin{array}{l}\text { Rs. 10,000 - Rs. } \\
\text { 20,000 }\end{array}$ & 61 & 30.5 & 42 \\
\hline $\begin{array}{l}\text { Rs. 20,000 - Rs. } \\
\text { 30,000 }\end{array}$ & 37 & 18.5 & 60.5 \\
\hline $\begin{array}{l}\text { Rs. 30,000 - Rs. } \\
\text { 40,000 }\end{array}$ & 13 & 6.5 & 67 \\
\hline Above Rs. 40,000 & 66 & 33 & 100 \\
\hline $\begin{array}{l}\text { No. of members } \\
\text { in the family }\end{array}$ & 40 & 20 & 18.5 \\
\hline $\begin{array}{l}\text { Below } \\
\text { Members }\end{array}$ & 100 & 50 & 68.5 \\
\hline 03 - 04 Members & 52 & 26 & 94.5 \\
\hline 04 - 05 Members & 8 & 4 & 98.5 \\
\hline $\begin{array}{l}\text { Above } \\
\text { Members }\end{array}$ & 200 & 100 & 280 \\
\hline Total & & & \\
\hline
\end{tabular}

Source : Primary Data.

Published By:

Blue Eyes Intelligence Engineering

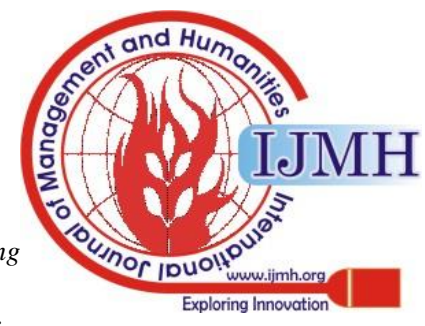


The above table 01 reveals that the respondents monthly income in the rangeRs $10,000-20,000$ is in 30.5 per cent of family members are in between03- 04 members.

Table 02: Preference of respondents' in buying Products:-

\begin{tabular}{|c|c|c|c|c|c|c|c|c|c|c|c|c|c|c|c|}
\hline & & & & & & & & & & & & Total & $\begin{array}{l}\text { Total } \\
\text { Score }\end{array}$ & WAS & Rank \\
\hline $\begin{array}{l}\text { Electronic } \\
\text { products }\end{array}$ & 81 & 34 & 18 & 13 & 11 & 14 & 5 & 5 & 5 & 3 & 11 & 200 & 1735 & 8.67 & 1 \\
\hline Percent & 41 & 17 & 9 & 6.5 & 5.5 & 7 & 2.5 & 2.5 & 2.5 & 1.5 & 5.5 & 100 & & & \\
\hline Clothes & 19 & 16 & 19 & 19 & 20 & 19 & 21 & 16 & 15 & 7 & 29 & 200 & 1203 & 6.01 & 5 \\
\hline Percent & 9.5 & 8 & 9.5 & 9.5 & 10 & 9.5 & 11 & 8 & 7.5 & 3.5 & 15 & 100 & & & \\
\hline Books & 19 & 30 & 11 & 13 & 12 & 9 & 16 & 20 & 24 & 31 & 15 & 200 & 1159 & 5.8 & 7 \\
\hline Percent & 9.5 & 15 & 5.5 & 6.5 & 6 & 4.5 & 8 & 10 & 12 & 16 & 7.5 & 100 & & & \\
\hline Games & 3 & 9 & 34 & 20 & 18 & 15 & 16 & 25 & 13 & 28 & 19 & 200 & 1099 & 5.5 & 8 \\
\hline Percent & 1.5 & 4.5 & 17 & 10 & 9 & 7.5 & 8 & 13 & 6.5 & 14 & 9.5 & 100 & & & \\
\hline Flowers & 3 & 5 & 13 & 30 & 23 & 25 & 20 & 19 & 14 & 17 & 31 & 200 & 1034 & 5.17 & 2 \\
\hline Percent & 1 & 2.5 & 6.5 & 15 & 12 & 13 & 10 & 9.5 & 7 & 8.5 & 16 & 100 & & & \\
\hline Tickets & 6 & 11 & 22 & 23 & 23 & 28 & 27 & 20 & 16 & 9 & 15 & 200 & 1183 & 5.91 & 6 \\
\hline Percent & 3 & 5.5 & 11 & 12 & 12 & 14 & 14 & 10 & 8 & 4.5 & 7.5 & 100 & & & \\
\hline
\end{tabular}

Source: Primary Data

The table 02 revels the performance of respondents' in buying Products orderly by using weighted average score base. Electronic Products, Flowers, clothes, Tickets, Books and Games are in orderly ranked respectively.

\section{CONCLUSION}

Now a days Web shopping is the mantra of selling items and it indicates slandered and exchange process. It indicates Youngsters get to buying items in their own premises. It helpful the customers to take considerations and prompts to take their own desired items.

\section{REFERENCES}

1. Syed Shah Alam, NorjayaMohd. Yasin (2010) Journal of

Marketing Development and Competitiveness 5(1), 71 - 78.

\section{Websites:-}

www.flipkart.com

www.yebhi.com

www.myntra.com

www.amazon.com
WAS= Weighted Average Score

\section{AUTHOR PROFILE}

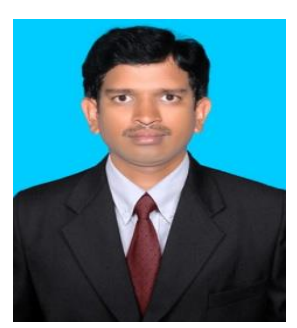

Khasimpeera.K, C/o. Rajamma D.NO.- 3/2020 Raja Reddy Street, Sionpuram, Kadapa - 516001 Mob: +91 9966367517

Email: khasim.mba2011@gmail.com

\begin{tabular}{|c|c|c|}
\hline \multicolumn{3}{|c|}{ Educational Credentials: } \\
\hline COURSE & INSTITUTION & $\begin{array}{l}\text { YEAR OF } \\
\text { PASSED }\end{array}$ \\
\hline M.B.A & s.v.university & 2013 \\
\hline M.COM & $\begin{array}{c}\text { Yogi vemana University } \\
\text { college, } \\
\text { vemanapuram }\end{array}$ & 2011 \\
\hline PGDCA & $\begin{array}{c}\text { J.R.Educational Trust } \\
\text { Computer Education and } \\
\text { Training. }\end{array}$ & 2008 \\
\hline B.COM & $\begin{array}{c}\text { Gov't degree college for men, } \\
\text { kadapa }\end{array}$ & 2007 \\
\hline
\end{tabular}




\begin{tabular}{|c|c|c|}
\hline $\begin{array}{c}\text { INTERMEDI } \\
\text { ATE } \\
\text { (CEC) }\end{array}$ & R.E.S.S.V. Jr college, khajipet. & 2002 \\
\hline SSC & $\begin{array}{c}\text { Z.P. Boy's High School, } \\
\text { khajipet. }\end{array}$ & 2000 \\
\hline \multicolumn{2}{|c|}{} \\
\hline
\end{tabular}

\section{Professional Career Summary:}

- $\quad$ Worked as Assistant Professor in Balaji institute of I.T \& Management, Kadapa.(01/09/2011 TO 11/12/2012)

- Working as Assistant Professor in K.S.R.M. Engineering college (AUTONOMOUS), Kadapa.(12/12/2012 TO Till Date )

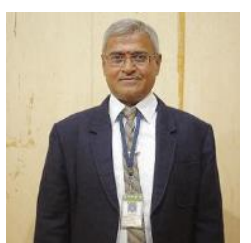

Dr. Sugunatha Reddy, M. Professor in Humanities and Sciences, KSRM College of Engineering E-mail: msnreddy1457@gmail.com Kadapa - 516 003. (A.P.) Contact No: 9966296511

\begin{tabular}{|c|c|c|}
\hline QUALIFICATION & UNIVERSITY & PERCENTAGE \\
\hline Ph.D & S.K. University & --- \\
\hline M. Phil & S.K. University & 65 \\
\hline M.A. & S.V. University & 62.5 \\
\hline PGDPM & ACG, New Delhi & 62 \\
\hline
\end{tabular}

A. TEACHING EXPERIENCE : 33 Years Worked as Teaching Assistant at KSRMCE, Kadapa From 16-07-1984 to 31-08-1986, as a Associate Lecturer From 01-09-1986 to 11-08-1992, as a Lecturer From 12-08-1992 to 11-08-1999, as a Assistant Professor From 12-08-1999 to 31-03-2017, as a Associate Professor \& HOD, Department of HSS

From 29-06-2017 to Till date , as Professor in Department of Humanities 